\title{
ТРУДОУСТРОЙСТВО ВЫПУСКНИКОВ РОССИЙСКИХ ВУЗОВ В СОВРЕМЕННЫХ ЭКОНОМИЧЕСКИХ УСЛОВИЯХ
}

\author{
(C) 2021 Петров Антон Маркович \\ кандидат экономических наук, доцент, ведущий научный сотрудник, \\ Научно-исследовательский институт развития образования \\ Российский экономический университет имени Г. В. Плеханова, Россия, Москва \\ E-mail: PETROV-AM2000@yandex.ru
}

Статья посвящена проблеме трудоустройства молодых специалистов в России. Молодые специалисты рассматриваются сегодня как основа экономического развития общества. При этом существуют определенные трудности их трудоустройства. В статье представлены существующие возможности помощи молодым специалистам в поиске работы.

Ключевые слова: высшее образование, трудоустройство выпускников, работодатели, рынок труда, информационные технологии, молодые специалисты.

\section{Введение.}

В условиях рыночной экономики, в которой преобладает частный сектор, представленный как крупными корпорациями, так и средними и малыми компаниями и организациями, а также в условиях современных социальноэкономических процессов и ухода от советской системы распределения выпускников вузов вопрос первого трудоустройства молодых специалистов, которые только закончили учебные заведения высшего образования и не имеют, в большинстве случаев, необходимого практического опыта работы по специальности, остается острым и важным для России.

Следует отметить, что молодежь характеризуется рядом определённых социальнопрофессиональных свойств: отсутствие практического опыта работы и трудовых навыков, неопределенность и изменчивость профессиональной ориентации, недостаточный уровень социализации (социальная незрелость), неадекватная самооценка и высокие требования к условиям и оплате труда. В связи с этими свойствами молодые специалисты, которые только закончили вузы, чаще всего подвергаются дискриминации на рынке труда [3, с. 54].

В свою очередь, как показывает общая практика, многие работодатели, осознавая уровень подготовки выпускников вузов, не всегда готовы брать молодых специалистов без опыта работы. Кроме того, несмотря на все большее включение работодателей в учебный процесс вузов (как возможность получения студентами практических навыков по профилю подготовки от экс- пертов), что продиктовано государственными образовательными стандартами, оно остается не всегда эффективным, что иногда демонстрирует, к примеру, формальное прохождение студентами практики на базе организаций и учреждений.

Кроме того, нехватка на рынке труда «хороших» рабочих мест (с достойной оплатой и условиями труда) для молодых специалистов по полученным ими специальностям приводит к нежеланию части выпускников работать по полученной профессии и заставляет их искать иные места для трудоустройства [10] (приводит молодежь к долгосрочным поискам работы).

Таким образом, проблемы с включением молодежи в трудовую деятельность остаются несмотря на то, что государство тратит каждый год огромные средства на обеспечение российских вузов бюджетными местами. Отметим, что в текущем году 576498 студентов смогут получить высшее образование бесплатно за счет бюджета государства. В ближайшее время число бюджетных мест для студентов еще увеличиться. При этом, как отмечается в Министерстве науки и высшего образования России, в ходе распределения в субъекты РФ сейчас направляется значительное число бюджетных мест [6].

В российских вузах также обучаются студенты и на коммерческой основе, которые платят сами за себя. Как показывает практика, коммерческие студенты для оплаты своего обучения в вузе либо специально для этого находят работу на неполный рабочий день, в большинстве случаев не по направлению подготовки, либо обращаются за финансовой помощью родителям или 
родственникам, либо используют возможность применить средства материнского (семейного) капитала, либо обращаются в финансовокредитные учреждения для получения кредита на образование.

Следует отметить, что Постановлением Правительства РФ от 24 декабря 2007 № 926 (с изм. и доп., вступ. в силу с 01.01.2021) был утвержден порядок направления средств (части средств) материнского (семейного) капитала на получение ребенком (детьми) платных образовательных услуг в любой организации на территории Российской Федерации, а также на иные связанные с получением образования ребенком (детьми) расходы.

Многие банки в России, как известно, предлагают абитуриентам воспользоваться на разных условиях образовательными кредитами, по которым, во многих случаях, средняя процентная ставка оказывается ниже, чем по обычным кредитам. У абитуриентов есть возможность получить также кредит на образование с господдержкой. Так, ПАО Сбербанк предлагает абитуриентам получить высшее образование, воспользовавшись их кредитом (для оплаты любого периода учебы: один семестр, год или всё обучение целиком) с частичным погашением задолженности по нему государством [4].

Поэтому, не только государству важно чтобы выпускники вузов трудоустроились и смогли начать приносить обществу экономическую пользу (в ходе участия в создании новых материальных и нематериальных благ, уплаты различных налогов и взносов в бюджетную систему страны), но и самим выпускникам вузов важно оперативно найти место работы для обеспечения достойного уровня жизни себя и близких.

Несмотря на существующие сложности и современные вызовы органы власти России предпринимают активные мероприятия, направленные на оперативное включение выпускников вузов в хозяйственную деятельность страны и ее регионов, на использование креативного мышления и новаторских идей молодежи для обеспечения интенсивного экономического развития государства.

Инициативы федеральных органов государственной власти в сфере трудоустройства выпускников вузов

Отметим, что к началу 2021 года в центрах занятости было зарегистрировано более 150 тысяч соискателей моложе 25 лет. При этом из них выпускников 2020 года, которые встали на учёт после 1 января 2021 года, составляет около 15 тысяч человек [9]. В целях снижения в России уровня безработицы среди молодежи, обеспечения повышения уровня их трудоустройства, в том числе выпускников образовательных организаций среднего профессионального и высшего образования, Министерство труда и социальной защиты РФ предпринимает определенные активные шаги. Отметим некоторые из них.

Так, к примеру, ведомством была запущена аналитическая система мониторинга трудоустройства выпускников на основании данных электронных трудовых книжек и системы персонифицированного учёта Пенсионного фонда. Этот проект данное ведомство реализует во взаимодействии с Рособрнадзором, Министерством просвещения и Министерством науки и высшего образования России [9]. Предполагается, что на основе полученной информации органы власти смогут более целенаправленно реализовывать мероприятия в отношении трудоустройства выпускников и эффективно реагировать на потребности работодателей на рынке труда.

В планах Министерства труда и социальной защиты РФ стоит реализация мер по обеспечению субсидирования работодателей (отмечается, что размер субсидии составит три минимальных размера оплаты труда), которые будут обеспечивать занятость выпускников, в том числе высших учебных заведений [2]. Подобные меры, но для научно-образовательного сектора, были отмечены в 2020 году руководителем Минобрнауки РФ: проведение субсидирования части расходов, которые понесут научные и образовательные организации, в ходе приема на работу выпускников 2020 года на должности исследователей.

Такая финансовая поддержка может в определенной степени дать положительный эффект. В Министерстве труда и социальной защиты РФ подчеркивают, что работодатели в основном не заинтересованы брать на работу выпускников по причине того, что им требуется в него “вложиться” для их адаптации к первому рабочему месту, т.е. работодатель несет определенные прямые и косвенные расходы [2].

Такие расходы особенно существенны для малых организаций и компаний, индивидуальных предпринимателей. При этом существует риск того, что после их адаптации молодой специалист может перейти с полученным прак- 
тическим опытом к другому работодателю. Поэтому в этой ситуации эффективность Минтруда России в области субсидирования работодателей, которые принимают выпускников, в т.ч. вузов, будет зависеть как от порядка осуществления такого субсидирования, так и от размера субсидирования.

Расширение возможностей трудоустройства для выпускников вузов должен дать еще один проект - размещение на портале «Работа в России» цифровой витрины стажировок и практик, где будут размещены приглашения работодателей, адресованные для студентов [5].

Следует отметить, что современные информационно-коммуникационные технологии, развитие и создание все новых социальных сетей, масштабное распространение интернета позволяет как работодателям оперативно информировать широкий круг соискателей о имеющихся у них вакансиях, так и соискателям презентовать себя значительному количеству работодателей.

Кроме того, с учетом современных достижений в области цифровых технологи и решений (когнитивные технологии, облачные технологии, Big Data и др.), процесс управления трудовыми ресурсами должен получить развернутую и более детальную цифровую интерпретацию $[1$, c. 58], что позволит добиться большей сбалансированности рынка труда и более точного прогнозирования спроса на кадры, в том числе молодых специалистов, в той или иной отрасли экономики.

Деятельность региональных органов государственной власти в сфере трудоустройства выпускников вузов

Кроме федеральных инициатив, региональные органы власти в свою очередь также реализуют мероприятия по поддержке занятости для тех, кто впервые ищет работу. К примеру, в Москве, Ленинградской, Волгоградской, Липецкой, Оренбургской и Сахалинской областях для выпускников вузов установлены квоты на рабочие места.

Регионы, несмотря на существующие у многих из них социально-экономические проблемы, заинтересованы в кадрах, в том числе в молодых специалистах. В настоящее время в ряде регионов страны действуют программы, мероприятия, которые призваны, наряду с федеральными инициативами, содействовать не только в трудоустройстве молодых специалистов, но и их удержанию у себя: создание новых рабочих мест, материальное поощрение (различные формы выплат из бюджета, предоставление жилья и т.п.) и др. [2].

Хорошим примером может служить закон города Москвы от 22 декабря 2004 года № 90 «О квотировании рабочих мест» (с изменениями на 30 апреля 2014 года). Из данного нормативноправого акта следует, что организации, с численностью работников более 100 человек, обязаны принимать на работу $2 \%$ кандидатов из числа молодежи. Кроме того, в Москве в целях помощи молодым специалистам, впервые вышедшим на открытый рынок труда, Центр занятости населения «Моя работа» запустил проект «Первая работа». Главная цель проекта - создание площадки для эффективного взаимодействия мотивированных молодых специалистов и работодателей на базе Центра занятости населения. Данный проект дает уникальную возможность молодежи воспользоваться помощью государства в своем первом трудоустройстве [8].

Сегодня в ряде субъектов РФ региональные органы власти в ходе тесного взаимодействия как с университетами, так и с работодателями активно реализуют мероприятия по обеспечению занятости студентов и выпускников вузов: реализация оплачиваемых стажировок от нескольких месяцев до полугода; формирование банка вакансий для молодых специалистов, выпущенных из вузов, а также информационной базы по выпускникам (электронный портфолио); проведение ярмарок вакансий и др.

Деятельность работодателей и российских учебных заведений высшего образования в сфере трудоустройства выпускников вузов

В настоящее время также наблюдать еще одна тенденция. В ходе взаимодействия между работодателями и вузами устанавливаются более тесные и плодотворные взаимоотношения между ними, которые ведут не только к обеспечению студентов вузов базой для прохождения практики, но и появлению за счет совместных усилий: новых образовательных программ; возможностей у студентов вузов пройти у работодателей различные стажировки с перспективой трудоустройства, получить профессиональную консультацию у работодателей по своей специальности, а также пройти экскурсии и иные ознакомительные мероприятия на предприятиях и компаниях работодателей и т.п. 
Отметим, что в мае-июне 2020 года Координационный совет по развитию сообществ молодых специалистов при Общественной палате Российской Федерации и Ассоциация граждан и организаций по содействию развитию корпоративного образования «МАКО» провели опрос крупных российских компаний («Газпром», «Газпром нефть», «Россети», «Башнефть», «Интер РАО», «Первоуральский новотрубный завод», «Квадра», «КуйбышевАзот», «НОВАТЭК», «Издательство «Просвещение»», «РусГидро», «СИБУР Холдинг», «ФосАгро», «Энел Россия», «Роскосмос», «Росэнергоатом», «Росатом», «Сбербанк») по востребованности ими выпускников вузов России. Представители компаний должны были ответить на вопрос, из каких образовательных учреждений (высших и средних профессиональных) они предпочитают набирать молодых специалистов для работы в свои компании. Среди российских вузов, которые получили значительное число положительных отзывов от компаний получили, к примеру, такие университет как: Национальный исследовательский университет «Высшая школа экономики», Московский государственный университет им. М. В.Ломоносова, Московский государственный технический университет им. Н.Э.Баумана, Томский политехнический университет, Санкт-Петербургский политехнический университет Петра Великого, Уральский федеральный университет им. первого Президента России Б.Н. Ельцина, Национальный исследовательский ядерный университет «МИФИ», Тюменский индустриальный университет и ряд др. (более подробней в источнике 11). Как отмечают организаторы опроса, большинство работодателей доверяют выпускникам тех вузов, с которыми у них уже установлены долгосрочные и системные партнерские отношения, осуществляются совместные программы целевой подготовки специалистов, проводятся различные профильные конкурсы студенческих проектов, а также открыты специальные учебные курсы и кафедры [11].

На базе самих университетов действуют специализированные структурные подразделения (Центры карьеры и трудоустройства), которые не только реализуют различные мероприятия по организации стажировок и практик для студентов, но и реализуют студентам и выпускникам меры по трудовой адаптации, проводят карьерное консультирование, оказывают помощь в поиске работы и т.п. В настоящее время для вузов важным становиться не только качественная подготовка специалистов, но и обеспечение их выхода на рынок труда и нахождения ими своей первой работы.

Сегодня все больше российских вузов нарабатывают успешную практику трудоустройства выпускников. Сегодня для вузов является важным установление тесного сотрудничества с работодателями: вузы привлекают к практическим и лекционным занятиям практиков, специалистов компаний из различных областей для повышения качества подготовки студентов; вузы выстраивают долгосрочные отношения с различными предприятиями и организациями в целях прохождения студентами на их базе практик и получения практических навыков и умений, получения опыта применения знаний, которые студенты получают в вузе; развиваются и такие форматы взаимодействия с работодателями как открытия базовых кафедр (большинство крупных компаний («Яндекса», Mail ru Group, ВТБ и др.[7]) уже создали базовые кафедры в профильных для своей отрасли вузах) и целевой приём (гарантированная возможность студентуцелевику получить рабочее место в организации, которая оплатила его обучение в вузе).

\section{Заключение.}

Таким образом, в современных условиях экономика России нуждается в активных и высококвалифицированных человеческих ресурcax, которые обеспечили бы ей интенсивный рост и международную конкурентоспособность. Для этого учебным заведениям нужно готовить востребованных у работодателей не только сейчас, но и в перспективе специалистов. Чтобы обеспечить трудоустройство выпускников российских вузов необходимы не только государственные меры на разных уровнях управления по установлению квоты на рабочие места для молодежи, по симулированию работодателей (к примеру, их субсидирование, применение налоговых льгот и т.п.), но и поддержка в целом реального сектора экономики, выражающаяся в расширении и открытий новых предприятий, на который могли бы трудоустраиваться молодые специалисты. Кроме того, активное применение и развитие механизма целевого обучения, по завершению которого выпускники вузов должны отрабатывать в организациях (компаниях), по инициативе которых они получали бесплатное высшее образование, может стать одним из способов обеспечения экономики востребован- 
ными и необходимыми кадрами. Практика создания компаниями в вузах базовых кафедр также является сегодня эффективным способом не только обеспечить практико-ориентированное обучение студентов, но и обеспечить их трудоустройство после выпуска, так как такие кафедры за счет работы на них высокопрофессиональных практиков, создания уникальных обучающих программ целенаправленно помогают студентам лучше узнать будущую специальность и сферу своей будущей работы.

\section{Библиографический список}

1. Волков Д.В. Целевое управление трудовыми ресурсами: задачи, программно-информационное обеспечение // Экономические науки. 2020. № 10. С. 58-63

2. Игнатова О. Минтруд предложил работодателям субсидии за трудоустройство выпускников [Электронный ресурс].- Режим доступа: https://rg.ru/2021/05/25/mintrud-predlozhil-rabotodateliam-subsidii-zatrudoustrojstvo-vypusknikov.html (дата обращения 05 июня 2021)

3. Колесникова Ю.С., Камашева А.В., Халиков А.Л. Молодежный рынок труда и содействие трудоустройству // Экономические науки. 2013 № 12 (109). С. 54-57.

4. Кредит на образование [Электронный ресурс]. - ПАО Сбербанк - Режим доступа: https://www.sberbank.ru/ ru/person/credits/money/credit_na_obrazovanie (дата обращения 21 мая 2021)

5. Манукиян E. Работодателей предложили поощрять за трудоустройство выпускников [Электронный ресурс].- Режим доступа: https://rg.ru/2020/08/02/rabotodatelej-predlozhili-pooshchriat-za-trudoustrojstvovypusknikov.html (дата обращения 11 июня 2021)

6. Минобрнауки России объявило результаты распределения бюджетных мест на 2022/2023 год. Новости Минобрнауки России. 29 апреля 2021. [Электронный ресурс].- Режим доступа: https://www.minobrnauki.gov. ru/press-center/news/? ELEMENT_ID=33254 (дата обращения 07 мая 2021)

7. Носкова Е. Бизнес ищет таланты [Электронный ресурс].- Режим доступа: https://rg.ru/2018/11/21/ rossijskomu-rynku-truda-ne-hvataet-it-specialistov.html (дата обращения 15 июня 2021)

8. Официальный интернет-ресурс Департамента труда и социальной защиты населения города Москвы [Электронный ресурс].- Режим доступа: https://dszn.ru/press-center/news/4685 (дата обращения 07 июня 2021)

9. Президент в режиме видеоконференции провёл совещание с членами Правительства [Электронный ресурс]. - Режим доступа: http://www.kremlin.ru/events/president/news/65566 (дата обращения 31 марта 2021)

10. Чередниченко Г.А. Положение на рынке труда выпускников системы высшего и среднего профессионального образования // Вопросы образования. 2020. № 1. С. 256-282.

11. 12 российских вузов, выпускники которых предпочитают нанимать крупные российские компании [Электронный ресурс].- МАКО - Режим доступа: https:/www.makonews.ru/2020/06/16/vedushhie-rossijskiekompanii-predpochitayut-nanimat-vypusknikov-12-vuzov/ (дата обращения 10 мая 2021) 